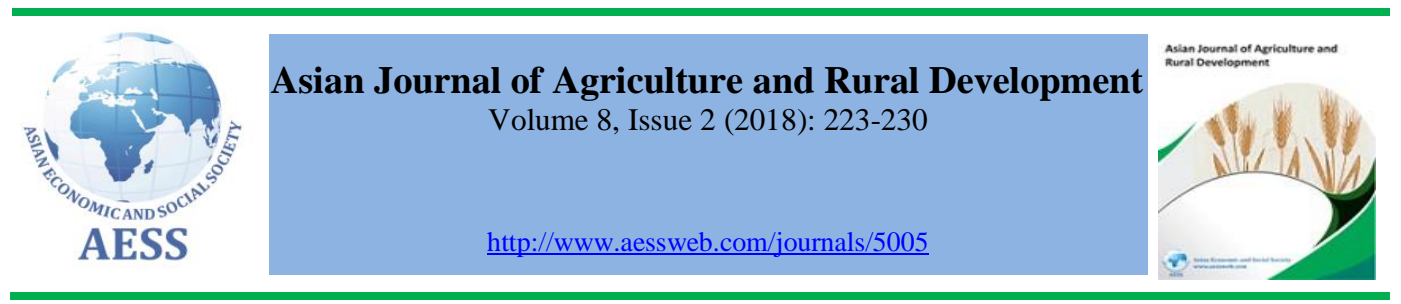

\title{
IMPLICATION OF RURAL POPULATION IN PLANNING LOCAL COMMUNITY DEVELOPMENT: A NEED FOR POLICY REFORM
}

\author{
Fon Dorothy Engwali Department of Agricultural Economics, Faculty of \\ Agronomy and Agricultural Sciences, University of \\ Mengue Melongo Priscille Dschang, Cameroon. \\ Grace
}

$\triangle$ dengwali@yahoo.fr (Corresponding author)

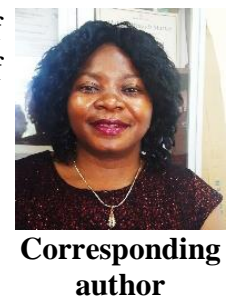

\section{ARTICLE HISTORY: \\ Received: $18-$ Nov-2018 \\ Accepted: 15-Jan-2019 \\ Online Available: 19-Feb- 2019}

\section{Keywords:}

Local community

development,

Planning,

Participation,

Participatory rural

appraisal,

Rural population

\begin{abstract}
It has been observed that the participation of rural population is not really massive in some localities during the process of planning local community development. Thus, this study seeks to identify factors which can influence the participation of an individual in the materialization of the planning process at the level of the village. Data was collected from 108 respondents with the help of a structured pretested questionnaire in Bonalea and Dibamba councils. The binary logistic regression was used to find the factors which can influence their participation in the planning process. The results show that the implication of an individual is influenced by his or her affiliation (membership) to a farmer's organization and the knowledge that a person has about the activities of the program. This suggests the need for the government to increase the sensitization about the activities of the program and the benefit of being a member of a farmer's organization. The origin of the family influenced their participation. A non-native of a locality does not find it important to take part in any development process in their host locality which therefore suggests the need for the government to realize a special plan for strangers in locality.
\end{abstract}

\section{Contribution/ Originality}

This study is important because it has been observed that the participation of rural population is low in some localities during the data gathering and analysis phase of planning for local community development. The involvement of the population is paramount in order to identify their real needs so as to help choose suitable development strategies and hence projects. Factors influencing the participation of individuals in the planning process at the village level are identified.

DOI: 10.18488/journal.1005/2018.8.2/1005.2.223.230

ISSN (P): 2304-1455/ISSN (E):2224-4433

How to cite: Fon Dorothy Engwali and Mengue Melongo Priscille Grace (2018). Implication of rural population in planning local community development: a need for policy reform. Asian Journal of Agriculture and Rural Development, 8(2), 223-230.

(C) 2018 Asian Economic and Social Society. All rights reserved. 


\section{INTRODUCTION}

The economic crises in African countries in the $80^{\mathrm{s}}$ and the pressure of the Bretton Woods institutions push the central government to adopt a new form of government which is the decentralization (Canone, 2007). In Cameroon, the law $N^{\circ} 2004 / 017$ of the 22 July 2004 concerning decentralization gave to local councils the responsibility to ensure local development. To help the councils in their work, the central government put in place some institutions and projects like the community development program project. This project which started in 2004 and is financed by funders such as the World Bank, the French Development Agency, and the State of Germany. It was planned that the project will have three phases of four years each. Their main goal is to realize the local development plans in all the councils of the country (Community development program project, 2008). Planning is a very important process. It can influence economic development, it can also enhance the ability of citizens to gain better access to decision making systems and to have their concerns heard, and, can work to ensure involvement of all sectors of the community (Cowichan Valley Safer Futures Program, 2004).

In the field, the planning process of the community development program project has several steps. At the level of the council, the diagnosis of the institutional council is done in order to analyze the institutional and the organizational situation of the council as an institution. The diagnosis of the urban area is another step in the planning process. It helps to know the characteristics of the urban area and identify the opportunities and the constraints of the urban area of the council. At the level of the villages, the participatory rural appraisal is realized in other to collect information from the rural population so that their real needs would be found in the local development plans (Community development program project, 2008). It is important to note that participatory rural appraisal is one of the most important steps in the planning process because it necessitates great participation of the rural population. They must put aside their current activities for four days in other to feed the development process. At the end of the planning process, all the priority projects of the locality are identified on a participatory approach and will be implemented by the council or other sponsors in order to increase the standards of living of the local population. Despite the importance of the participatory rural appraisal, the mobilization of the population is not really what it is expected to be (Henry, 2008). The objective of this study is to identify the factors that can influence the participation of an individual through the participatory rural appraisal especially in non-centralized society like those of the Littoral region of Cameroon where the community spirit is not very developed.

\section{METHODOLOGY}

\subsection{Study population, a unit of analysis and sampling technique}

The study population composed of all the socio-professional groups of Dibamba council in the Sanaga-Maritime Division and Bonalea council in the Wouri Division in the Littoral Region of Cameroon. Under Cameroon law-Article 52 of Order No. 81-02 of June 29, 1981, a girl must be 15 years old to marry and a boy must be 18 and thus only persons of at least 15 years made up the study population

The multistage stratified random sampling procedure was used which involved the following: in stage one, there was a random selection of the two divisions out of a total of four divisions (Moungo, Nkam, Sanaga-Maritime and Wouri) that comprise the Littoral Region of Cameroon. The two randomly chosen divisions include Moungo and Sanaga-Maritime. In stage two, two subdivisions were purposively selected from the previously chosen divisions. This is because during the participatory rural appraisal, the participation of the local population in these subdivisions were very low compare to others. This brought the study area to two subdivisions (Bonalea and Dibamba). In stage three, four villages were randomly selected from each of the two 
subdivisions initially selected. This brought the total number of villages to four (04) namely: Magamba and Banseng in Bonalea council, Missolè II and Sikoum in Dibamba council. In stage four, 108respondents were randomly selected from thefour villages 30 each from Magamba and Banseng; 20 from Missolè II and 28 from Sikoum. These ratio were randomly obtained on the basis of people who were available to participate in the interviews in each locality. The unit of analysis was the individual inhabitant of the said localities in the Littoral Region of Cameroon.

\subsection{Validity and reliability of survey instrument}

The instrument used in this study consisted of a list of questions developed following an extensive review of the literature. The questions were carefully phrased to ensure consistency of inquiry. The researchers issued the questionnaire to an odd numbered committee of experts for possible clarity, relatedness, and evaluation (for validity). The questionnaire consisted of three subheadings with a varied number of items under each subheading. The questionnaire was pre-tested with 08 randomly selected individual of the population to discern the extent to which the instrument was understandable.

\subsection{Data collection and analysis}

Data were obtained only from primary source. The data were collected using a set of structured and pre-tested questionnaires, which were administered to the inhabitant from each of the councils (Bonalea and Dibamba). Combinations of both open and close-ended questions were used. The technique of data collection was reactive. The questionnaire provided information on personal and socio-economic characteristics of the respondents, their knowledge about the community development program project and the factors which can impede their participation in the participatory rural appraisal. The data collected were subjected to descriptive and inferential statistics.

\subsection{Method of data analysis}

The data were analyzed with the aid of SPSS version 14, using frequency and percentage. Data collected from the sample population was analyzed both qualitatively and quantitatively. The socio-economic characteristics of the respondents were analyzed with the help of descriptive statistical tools such as frequency tables and percentages, while the factors which can influence the participation in the planning process was addressed through the use of inferential statistical tools viz., binary logistic regression model. The logit model is more convenient because the dependent variable is qualitative in nature, the explanatory variables are a mix of continuous and qualitative variables, and the sample size is low ( $\mathrm{N}=108)$ (Gujarati, 1995; Terrell, 1999; Wooldridge, 2009). The logit model is used to predict the probability of the occurrence of the event, that is, the natural $\log$ of the odds ratio of having made one or the other decision (Participation or Non-participation). By denoting $P$ as the probability of making such decision from the predictors $X_{1}$ to $X_{11}$, the mathematical formulation of the logit model used in this study is expressed in equation (1) such as:

$$
Y=\operatorname{Logit}(P)=\log (P / 1-P)=a+b_{1} X_{1}+b_{2} X_{2}+\ldots \ldots \ldots \ldots+b_{11} X_{11}
$$

Where: P: is the predicted probability of the occurrence of event (Participation); 1-P: is the predicted probability of non-occurrence of event (non-participation); Y: participation of an individual in the participatory rural appraisal (coded as $1=$ Participation, $0=$ Non participation); $\mathrm{X}_{1}$ : age of the individual (in years); $\mathrm{X}_{2}$ : gender of member (coded as $1=$ male, $0=$ female); $\mathrm{X}_{3}$ : Origin of the family (coded as: $1=$ Non-native ; $0=$ Native); $\mathrm{X}_{4}$ : level of education (coded as $1=$ Secondary and less; $0=$ University ); $\mathrm{X}_{5}$ : Marital status (coded as $1=$ Married; $0=$ Non married); $\mathrm{X}_{6}$ : External agent perception (coded as $1=\mathrm{Good} ; 0=\mathrm{Bad}$ ); $\mathrm{X}_{7}$ : Farmer organization membership (coded as $1=$ Yes; $0=\mathrm{No}$ ); $\mathrm{X}_{8}$ : Implicate in a conflict with a member of the community (coded as $1=$ Yes; $0=\mathrm{No}) ; \mathrm{X}_{9}$ : Knowledge of the community development project program $(1=$ yes, $0=$ 
no); $\mathrm{X}_{10}$ : Experience of the governmental action(coded as $\left.1=\mathrm{Good} ; 0=\mathrm{Bad}\right) ; \mathrm{X}_{11}$ : Social position ( ( coded as $1=$ Normal citizen ; $0=$ Elite; $)$.

The exponentials $\operatorname{Exp}(\mathrm{B})$ of the slope coefficients $\beta \mathrm{k}$ associated to the explanatory variables are interpreted as the Odds Ratio (OR) of the occurrence of the event (participation in the participatory rural appraisal) for each increase in the predictor. A positive $\beta \mathrm{k}$ coefficient generally displays an OR greater than one $(\mathrm{OR}>1)$ whereas a negative $\beta \mathrm{k}$ coefficient usually indicates an OR lower than one $(\mathrm{OR}<1)$. Usually, the expression 1/Exp (B) designates the inverse OR which is computed in order to facilitate the interpretation of the variables with negative coefficients (Gujarati, 1995; Terrell, 1999; Wooldridge, 2009).

\section{FINDINGS}

This section discusses the results based on the methodology explained in the preceding section. It begins with descriptive statistics, which was utilized to present the socio-economic characteristics of the respondents.

Table 1: Socio-economic characteristics of the respondents

\begin{tabular}{|c|c|c|c|c|}
\hline & \multicolumn{2}{|c|}{ Bonalea } & \multicolumn{2}{|c|}{ Dibamba } \\
\hline & Frequency & Percentage & Frequency & Percentage \\
\hline \multicolumn{5}{|l|}{ Gender } \\
\hline Male & 37 & 61.67 & 33 & 68.75 \\
\hline Female & 23 & 38.33 & 15 & 31.25 \\
\hline Total & 60 & 100.00 & 48 & 100.00 \\
\hline \multicolumn{5}{|l|}{ Age } \\
\hline$<20$ & 0 & 0.00 & 2 & 4.17 \\
\hline $21-30$ & 6 & 10.00 & 19 & 39.58 \\
\hline $31-40$ & 9 & 15.00 & 11 & 22.92 \\
\hline $41-50$ & 14 & 23.34 & 9 & 18.75 \\
\hline $51-60$ & 11 & 18.33 & 6 & 12.50 \\
\hline $61-70$ & 10 & 16.67 & 1 & 2.08 \\
\hline $71-80$ & 8 & 13.33 & 0 & 0.00 \\
\hline$>80$ & 2 & 3.33 & 0 & 0.00 \\
\hline Total & 60 & 100.00 & 48 & 100.00 \\
\hline \multicolumn{5}{|l|}{ Origin of the family } \\
\hline Natives & 42 & 70.00 & 16 & 33.33 \\
\hline Non natives & 18 & 30.00 & 32 & 66.67 \\
\hline Total & 60 & 100.00 & 48 & 100.00 \\
\hline \multicolumn{5}{|l|}{ Marital status } \\
\hline Single & 25 & 41.7 & 25 & 52.08 \\
\hline Married & 24 & 40 & 21 & 43.75 \\
\hline Widow & 11 & 18.3 & 2 & 4.17 \\
\hline Total & 60 & 100 & 48 & 100.00 \\
\hline \multicolumn{5}{|c|}{ Farmer organization membership } \\
\hline None & 19 & 31.67 & 17 & 35.42 \\
\hline Common Initiative group & 29 & 48.33 & 13 & 27.08 \\
\hline Njangi & 1 & 1.67 & 3 & 6.25 \\
\hline Association & 11 & 18.33 & 15 & 31.25 \\
\hline Total & 60 & 100.00 & 48 & 100.00 \\
\hline \multicolumn{5}{|c|}{ Participation in participatory rural appraisal } \\
\hline Yes 1 & 22 & 36.70 & 7 & 14.58 \\
\hline
\end{tabular}




\begin{tabular}{lcccc}
\hline No & 38 & 63.30 & 41 & 85.42 \\
Total & 60 & 100.00 & 48 & 100.00 \\
\hline
\end{tabular}

From Table 1, it can be observed that most of the respondents in both councils (Bonalea $68.75 \%$ and Dibamba 61.67\%) were men. These result are similar to the findings of Diallo (2008) for the Koumban council in Guinea but different from the findings of Hamenou (2009) who found out in his study of rural population participation in project of Togo that women were more participative than the men. Results in the table also show that mature people (ages Above 50 years) were found more in Bonalea $(51.66 \%$ ) compare with Dibamba where most of the respondents were youths( less than 50 years) $85.42 \%$. Most of the respondents were in the age range of $31-60$ which is in line with the findings of Hamenou (2009). There are more natives in Bonalea compare to Dibamba were the great majority of the respondents were strangers. This could be attributed to the fact that the quarry and agro-industries (Cameroon Development Corporation and the Cameroon Society of Palm plantation are situated away from Bonalea but near to Dibamba where the non-natives, mostly of secondary school education level, who settled to find work. Furthermore, the results show that a slight majority of the respondents in the two councils were single and few were members of a farmer organisation. Taking in to consideration all these socio-economic characteristics, the participation of the population in the participatory rural appraisal were low in Dibamba compare to Bonalea. These findings are similar to those of Lowe et al. (1999) who stipulate that youths are less likely to take part in any development activity compared with mature people. These results are also similar with the statement of Blondiaux (2005) which states that natives of a community are more likely to participate in the development of their locality compare to strangers.

The dependent variable participation of an individual in the participatory rural appraisal can be categorized as "Yes $=1$ " and "No $=0$ ". These were the two possible outcomes for the response variable and hence binary logistic regression was used. Results are presented in Table 2.

Table 2: Logistic regression analysis - factors influencing the participation in the planning process

\begin{tabular}{lcccc}
\hline Independent variables & B & Sig & $\operatorname{Exp}(\mathbf{B})$ & 1/Exp(B) \\
\hline Age & 0.024 & 0.152 & 1.024 & $/ /$ \\
$\begin{array}{l}\text { Gender } \\
(0: \text { Female ; }: \text { Male })\end{array}$ & -0.270 & 0.622 & 0.763 & 1.31 \\
$\begin{array}{l}\text { Origin of the family } \\
(0: \text { Native } ; 1: \text { Non-native })\end{array}$ & -0.199 & 0.695 & 0.819 & 1.22 \\
$\begin{array}{l}\text { Level of education } \\
(0: \text { secondery and less, } 1: \text { University })\end{array}$ & -20.878 & 0.999 & 0.000 & +Infinite \\
$\begin{array}{l}\text { Marital status } \\
(0: \text { Non married ; }: \text { Married })\end{array}$ & 0.591 & 0.236 & 1.806 & $/ /$ \\
$\begin{array}{l}\text { External agent perception } \\
(0: \text { Bad, } 1: \text { Good })\end{array}$ & 0.230 & 0.687 & 1.259 & $/ /$ \\
$\begin{array}{l}\text { Farmer organization membership } \\
(0: \text { No, } 1: \text { Yes })\end{array}$ & $1.224 * *$ & 0.045 & 3.400 & $/ /$ \\
$\begin{array}{l}\text { Implicate in a conflict with a member of } \\
\text { the community } \\
(0: \text { No, } 1: \text { Yes })\end{array}$ & -0.374 & 0.471 & 0.688 & 1.45 \\
$\begin{array}{l}\text { Knowledge of the community development } \\
\text { project program } \\
(0: \text { No, } 1: \text { Yes })\end{array}$ & $1.106 *$ & 0.054 & 3.023 & $/ /$ \\
\hline \begin{tabular}{l} 
Experience governmental action \\
\hline
\end{tabular} & 0.313 & 0.570 & 1.367 & $/ /$ \\
\hline
\end{tabular}




\begin{tabular}{|c|c|c|c|c|}
\hline $\begin{array}{l}(0: \text { Bad }, 1: \text { Good }) \\
\text { Social position }\end{array}$ & & & & \\
\hline ( 0 : Elite, 1 : Normal citizen $)$ & 0.632 & 0.344 & 1.882 & // \\
\hline Constant & $-4.223 * *$ & & & \\
\hline
\end{tabular}

$* * *, * *$ and $*$ is significant at $1 \%, 5 \%$ and $10 \%,-2$ Loglikelihood $=106,635$ Nagelkerke $R^{2}=0.235$, Percentage of correct prediction $=73.1 \%$ Omnibus

Test of Model Coefficients: $\chi^{2}=19,029 *$

Table 2 shows the logit model results for the factors influencing the participation of an individual in the participatory rural appraisal in Bonalea and Dibamba councils in the Littoral Region of Cameroon. The overall goodness-of-fit measured by the significance of the Chi-Square statistic in the Omnibus test of model coefficients is high $\left(\chi^{2}=19,029\right.$, significant at $10 \%$ level $)$. The percentage of the model's correct prediction is reasonably good $(73.1 \%)$. In general, the coefficients of the explanatory variables show the expected signs.

The variable farmer organization membership is significant at 5\% level. This implies that people who are belonging to farmer organization are more likely to participate in the participatory rural appraisal. This finding is similar to those of Hounmenou (2003) who found that members of farmer's organization are more implicated in the development of their community.

Otherwise, the people who have knowledge of the activities of the community development project program are more likely to participate in their activities compare to people who are not informed. This result is significant at $10 \%$ level. The results support the findings of Chauveau and Lavigne (1996) who found out that the more an individual has knowledge about a project the more he has the possibility to participate in the project.

Although the age shows an insignificant coefficient, when the age of an individual increase by one year, the probability to participate in the planning process increase by 1.024 . It means that a mature person participates more in the development of their locality than a youth. This result is in line with the findings of Lowe et al. (1999) who found out that the youths are not very implicated in the development of their community.

Gender has no significant influence on the participation of a person in the planning process regarding these results. But, men are less likely to participate in the participatory rural appraisal compare to women. These results are contrary to those obtained by Lowe et al. (1999) who concluded that the women are marginalized and thus are not very implicated in the development of their community.

Meanwhile, the origin of the family has an insignificant coefficient, the strangers or non-native of a community have a less probability to take part in any development aspect of their host community. This finding is similar with those of Blondiaux (2005).

The level of education has no significant coefficient but the result shows that educated people have a low probability to take part in the planning process. This result can be explained by the fact that a weak proportion of post-graduate individual has been found during the survey and none took part in the development process.

In contrast, the marital status has no significant influence in the participation of a person on the participatory appraisal. However, married people have a great probability to be implicated in any development process compare to those who are single or widow. 
The perception of an external agent by the individual has no significant influence on the participation of an individual in the participatory appraisal. However, people who have a good perception about external agent have a great probability to take part in this development process because it is done by an external agent. These findings are in line with (Monnet and Langlois, 2002) who stated that people talk easily with another person when they have enough confidence in them.

Despite the fact that the factor 'implicate in a conflict' has no significant coefficient, the binary regression logistic model shows that when an individual has a conflict with another member of his community, this person has a weak probability to take part in the planning process. These results are in line with Bajeddi (2002) which states that nowadays, people are more self-centered and are not able to overcome their personal feelings for the development of the community.

The experience of a governmental action has no significant influence on the dependent variable. However, a person who have a good experience with a governmental action have a great probability to take part in the planning process compare to those who have a bad experience of any governmental action. Hounmenou (2003) shared the same point of view.

Furthermore, the social position of an individual has no significant influence on the dependent variable. However, a person who considers herself or himself as a normal citizen has a great probability to take part at the participatory rural appraisal compared to elites who are not living in their villages most of the time. These results are contrary to the findings of Polère (2007) who found out that it is the elites that have the trend to take part in any development process.

\section{CONCLUSION}

The participatory rural appraisal is one of the most important aspects of the planning process. Even though the participation of the population is not really massive in some communities like Bonalea and Dibamba in the Littoral region of Cameroon, with the help of the socio-economic characteristic of the respondents and the binary regression model, this study shows that people who take part in the participatory appraisal are people who are married mature women, native of the community, they belong to farmer organization. They are also people who are aware of the activity of the project, have a good experience with governmental action and are normal citizen.

Hence, the government should set a system that would involve more people in the planning process especially strangers and youths of a community. This is because in Dibamba, the mobilization was very low because of those reasons. For the youths, the government with the help of the project must increase the sensitization by giving them all the benefits to take part in their development. To increase the participation of strangers, the government must impose their participation in the planning process by reserving a part in the process where they have to state their needs in their host locality.

Regarding the results of the logit model, the project must increase the sensitization because the variable 'Knowledge of the community development project program' is significant. More specifically, the project must multiply the sensitization to those who do not have access to television or radio by giving them track with the local language with the information about the program. Although, the variable 'belonging to farmer organization' is significant, the government must create awareness and sensitize the population to all the benefits of joining a farmer organization. 


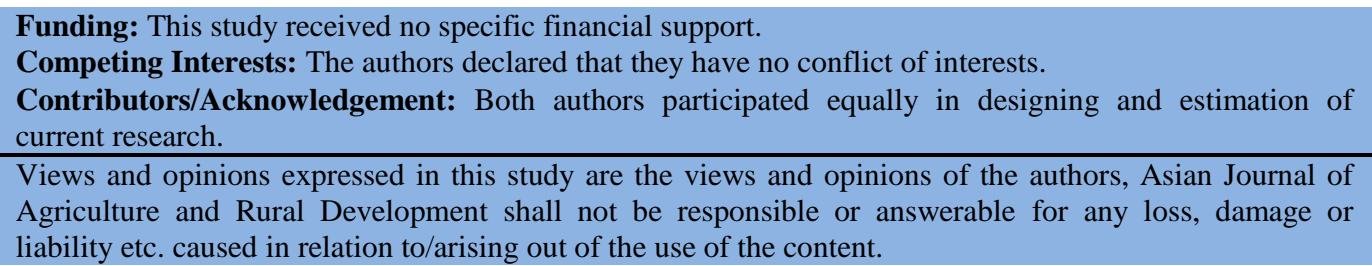

\section{References}

Bajeddi, M. (2002). Decentralization and implementation of participatory rural development strategies in Morocco. National Center of Documentation, Morocco.

Blondiaux, L. (2005). Deliberative democracy and participatory democracy: a critical reading. Conference of the MCD Chair, Retrieved from http://www.chaire-cd.ca.

Canone, A. (2007). Decentralization in sub-Saharan Africa: historical reminders and current context. Retrieved from http://aitec.reseau-ipam.org.

Chauveau, J. P., \& Lavigne, D. (1996). NGOs and development: from north to south (Africa, Latin America, Asia). Talence: ORSTOM.

Community development program project (2008). Manual of execution of the second phase. Cameroon: Community development program project.

Cowichan Valley Safer Futures Program (2004). Planning for safer communities. USA: CWAV

Diallo, A. (2008). People's participation in local development: the case of the rural commune of Koumban, Kankan prefecture (Guinea). Guinea: Julius N'yerere University.

Gujarati, D. N. (1995). Basic econometrics (third edition). McGraw-Hill: New York, USA.

Hamenou, K. (2009). Degree of participation of local populations in the projects of "SOS Children's Village Togo": case of the strengthening program of the Lome Children's Village. Ouagadougou: International Institute of Water and Environment.

Henry, A. (2008). Culture and management in Cameroon: the respect of the rituals, source of a friendly agreement. Quebec: University of Laval.

Hounmenou, G. (2003). New ways of coordinating actors in local development: the case of rural areas in Benin. Sustainable development and territories. Sustainable Development and Fragile Territories Network, France.

Lowe, P., Warsd, N., Wood, D., \& Woodward, R. (1999). Participation in rural development. Center for rural economy, Ireland.

Monnet, S., \& Langlois, M. (2002). Rural participatory diagnoses: the example of the Shepacc project in the Philippines. International handicap, Lyon.

Polère, C. (2007). "Participatory democracy": state of play and initial balance sheet elements. Lyon: Millennium: The center of prospective resources.

Terrell, G. R. (1999). Mathematical statistics: unified introduction. Springer-Verlag: New York, USA.

Wooldridge, J. M. (2009). Introductory econometrics: a modern approach. McGraw-Hill: New York, USA. 